\title{
The Origin of 7a-Hydroxy-Dehydroepiandrosterone and Its Physiological Role: a History of Discoveries
}

\section{STÁRKA}

${ }^{1}$ Institute of Endocrinology, Prague, Czech Republic

Received February 14, 2017

Accepted March 20, 2017

\begin{abstract}
Summary
Nearly 60 years has elapsed since the first isolation and identification of 7a-hydroxy-dehydroepiandrosterone, and in that time much information has been gained on its occurrence, metabolism, ontogeny, immunomodulatory activity, cell proliferation, cortisol control in local tissues and neuroactivity. Additional knowledge about this steroid may elucidate its role in obesity, neurodegenerative disturbances such as Alzheimer's disease, or psychiatric disorders such as schizophrenia or depression. This review aims to provide a comprehensive summary of the available literature on 7a-hydroxydehydroepiandrosterone.
\end{abstract}

\section{Key words}

Dehydroepiandrosterone • 7a-hydroxy-dehydroepiandrosterone • Neurosteroid $\bullet$ Occurrence $\bullet$ Immunomodulatory effects $\bullet$ CYP7B - 11ß-hydroxysteroid dehydrogenase

\section{Corresponding author}

L. Stárka, Department of Steroid Hormones, Institute of Endocrinology, Národní 8, 11694 Prague 1, Czech Republic. E-mail: Istarka@endo.cz

\section{Early studies}

7 $\alpha$-hydroxy-dehydroepiandrosterone $\quad(3 \beta, 7 \alpha$-dihydroxy-androst-5-en-17-one; 7-OH-DHEA), known initially from the microbial transformation of dehydroepiandrosterone (DHEA), was first isolated from human material by Okada et al. (1959) in the urine of a patient with adrenal carcinoma. In 1961 we published a simple method of 7-hydrox-DHEA synthesis that yielded both $\alpha$ and $\beta$ isomers with a prevalence of the $\alpha$-epimer (Stárka and Syhora 1960, Stárka 1961). The crystalline compound obtained enabled us to perform the chromatographic isolation and identification of $7 \alpha-\mathrm{OH}-$ DHEA, and in minor concentrations also of the $7 \beta$-isomer, in the urine (Stárka et al. 1962) and plasma (Stárka and Hampl 1964) of healthy men and women, as well as to study the hepatic (Stárka and Kůtová 1962) and extrahepatic (Šulcová and Stárka 1963, Stárka 1965) 7-hydroxylation of DHEA. 7-hydroxylation was found to be common in various organs of experimental animals (rats, frogs, horses), increasing in the order adrenals muscle - heart - liver - lung - spleen (Šulcová and Stárka 1963). The ontogeny of 7-OH-DHEA was studied in the human embryo, chorion, amniotic epithelium and amnion (Šulcová et al. 1967, Šulcová et al. 1968, Šulcová et al. 1976, Šulcová et al. 1982), with 7-hydroxylation of DHEA found to be starting at the $7^{\text {th }}$ week of gestation and a maximum occurring at the $22-23^{\text {rd }}$ week. 7-hydroxylation in a rat liver homogenate (Stárka and Kutová 1962) and by hepatic microsomal fraction was described and characterized nearly simultaneously by several authors (Šulcová and Stárka 1968, Heinrichs and Colás 1968, Heinrichs et al. 1967).

The further metabolic transformation of $7-\mathrm{OH}-$ DHEA was mainly studied in the liver, where depending on conditions the oxidation yielded 7-oxo-DHEA, $7 \alpha$-hydroxy-androst-4-ene-3,17-dione and $7 \alpha$-hydroxytestosterone, whereas incubation of 7-oxo-DHEA with rat liver slices led to the reduction of the 7-oxo-group under the formation of $7 \alpha$ - and $7 \beta$-hydroxy-derivatives at an approximate ratio of 1:1 (Hampl and Stárka 1967). We also studied the epimerization of $7 \alpha / \beta$-hydroxy-DHEAs and of steroid allyl-alcohols in general (Hampl and Stárka 
1969). Hepatic 7-hydroxylation and formation of the 7-oxo-derivative was also found in human embryos in the $7^{\text {th }}$ week of gestation and later (Šulcová et al. 1967). The formation of sulphate, either by sulphatation of the 3 $\beta$-hydroxy-group of 7-OH-DHEA or direct 7-hydroxylation of DHEA-sulphate, was then described in detail (Stárka et al. 1967). Aromatization of 7-OHDHEA occurs in the ovary and placenta (Cedard et al. 1964, Janata et al. 1965, Stárka et al. 1966). Human skin was found to be an important organ for 7-hydroxylation (Faredin et al. 1969), and intensive 7-hydroxylation of DHEA was found in a mammary carcinoma (Couch et al. 1975). Later, the relationship of 7-OH-DHEA in plasma to the stage of mammary carcinoma was demonstrated (Skinner et al. 1980).

After the pioneering research on 7-OH-DHEA in the sixties, nearly one generation passed before major further discoveries were made showing the importance of this steroid. Research was accelerated by the hypothesis that DHEA is a ,hormone of youth" and that its metabolites could participate in this role (Baulieu 1996).

\section{Enzyme system responsible for 7-hydroxy- lation of DHEA}

The 7-hydroxylation of dehydroepiandrosterone was later confirmed in various tissues (adrenals, testis, liver), including the brain (Akwa et al. 1992, Akwa et al. 1993, Doostzadeh and Morfin 1996, Doostzadeh et al. 1997, Rose et al. 1997, Morfin and Stárka 2001, Chalbot and Morfin 2005a, Chalbot and Morfin 2012) and adipose tissue (Khalil et al. 1993, Khalil et al. 1995). The metabolism of DHEA and related 7-hydroxylated derivatives in human liver S9 fractions (Chalbot and Morfin 2005b) and in specific regions of the brain was also described (Weil-Engerer et al. 2003, Li and Bigelow 2010).

The enzyme system responsible for the 7-hydroxylation of DHEA was characterized in more detail in the liver, brain and prostate (Tabei et al. 1975, Doostzadeh and Morfin 1966, Doostzadeh et al. 1997, Doostzadeh et al. 1998, Attal-Khémis et al. 1998b, Robinzon et al. 2004, Chalbot and Morfin 2005a,b, Chalbot and Morfin 2006, Kim et al. 2004, Trap et al. 2005, Martin et al. 2001). Different P450s were found to be involved in the $7 \alpha$ - and $7 \beta$-hydroxylation of DHEA, and that in addition to CYP7B1 7-hydroxylase (identical to cholesterol 7-hydroxylase), CYP7B2 also takes part in the 7-hydroxylation of DHEA. A comparison of these findings with those obtained with brain microsomes suggested that tissue-specific $\mathrm{P} 450$ species are responsible for the $7 \alpha$ - and $7 \beta$-hydroxylation of DHEA (Doostzadeh et al. 1998). Microsomes contained most of the activity, except for in the brain where mitochondrial activity was primary (Doostzadeh and Morfin 1996). The system responsible for the 7-hydroxylation of 5-enesteroids was fully characterized (Stapleton et al. 1995, Rose et al. 1997, Rose et al. 2001). It was concluded that Cyp $7 \mathrm{~b}$ is a $7 \alpha$-hydroxylase participating in the synthesis of the neurosteroids $7 \alpha$-hydroxy-DHEA, and $7 \alpha$-hydroxypregnenolone in brain. This system differs from cholesterol 7-hydroxylase, and genomic Southern analysis has suggested that a single gene corresponding to CYP7B1 (also known as het-1) is present in the mouse, rat, and human. CYP7B1 is unusual in that, unlike all other CYPs described until now, the primary site of expression is in the brain. Findings suggest that nuclear factor- $\kappa \mathrm{B}(\mathrm{NF}-\mathrm{\kappa B})$ and activator protein $\mathrm{AP}-1$ are involved in the tumor necrosis factor- $\alpha$ (TNF- $\alpha$ ) enhanced formation of the dehydroepiandrosterone metabolite 7 $\alpha$-OH-DHEA (Dulos et al. 2005). The ontogeny of the 7-hydroxylation system was also mapped in the mouse embryo (Bean et al. 2001).

For the preparation of pure 7-OH-DHEA, the 7-hydroxylation of DHEA in Saccharomyces cerevisiae (Vico et al. 2002) and Mucor racemous (Li et al. 2005) were used, and it was proposed that this system may reflect the conservation of an early signaling pathway of non-enzymatic reactions (Lathé 2002).

\section{The effects of 7-OH-DHEA}

As could be expected from the fact that molecular oxygen is essential for enzymatic 7-hydroxylation, antioxidant activity was found for DHEA and 7-OH-DHEA (Pelissier et al. 2004). The latter steroid exerted its anti-oxidant effect earlier than DHEA and mainly in the liver. As DHEA was found to possess an anti-glucocorticoid activity, it was crucial to determine whether its 7-oxygenated metabolites also exert such an effect. The anti-glucocorticoid activity of 7-OH-DHEA was demonstrated e.g. on the viability of plaque forming cells of cultured murine spleen lymphocytes incubated with dexamethasone (Hampl et al. 2000b). As for DHEA, no specific receptors were found for 7-OH-DHEA and no binding to the glucocorticoid receptors could be demonstrated (Stárka et al. 1998, Muller et al. 2004, Muller et al. 2006). 
An important contribution to the question of the role of 7-OH-DHEA was made by Chalbot and Morfin (2006). First, they demonstrated that 7-hydroxylated steroids produced in human tonsils enhance the immune response to tetanus toxoid and Bordetella pertussis antigens (Lafaye et al. 1999), and that second, the dexamethasone-induced apoptosis of mouse thymocytes is prevented by native $7 \alpha$-hydroxysteroids (Chmielewski et al. 2000). A similar effect was observed in murine spleenocytes (Šterzl et al. 1999). Several authors (Morfin and Courchay 1994, Morfin et al. 2000, Hampl et al. 1997, Hampl et al. 2001) published further proof that 7-hydroxylated steroids are involved in a process that may participate in the physiological regulation of the body's immune response. Immunomodulatory cytokines in seminal plasma correlated with the content of 7-OHDHEA (Hampl et al. 2000a,b, Pohanka et al. 2002, Šterzl et al. 2003). In rats with colitis, anti-inflammatory effects and changes in prostaglandin patterns were produced even more intensively by 7-hydroxy-epiandrosteron, a metabolite of 7-OH-DHEA (Hennebert et al. 2007c). An anti-proliferative activity of 7-oxygenated-DHEA metabolites that is not induced by inhibiting G6PD (glucose-6-phosphate dehydrogenase) or HMGR (3-hydroxy-3-methyl-glutaryl-coenzyme A reductase) activity alone was also observed (Yoshida et al. 2003).

\section{7-OH-DHEA in the brain}

Numerous authors have paid attention to the presence and role of 7-oxygeneted dehydroepiandrosterone derivatives in the brain (for review see Morfin and Starka 2001).

7-hydroxylated derivatives of dehydroepiandrosterone were found in the human ventricular cerebrospinal fluid (Stárka et al. 2009, Kancheva et al. 2011) and were compared with serum levels (Kancheva et al. 2010) in women with hydrocephalus. In shunt cerebrospinal fluid, 7-OH-DHEA could be even used as a prognostic factor for the success of surgical therapy (Sosvorová et al. 2012, Sosvorová et al. 2015a,b).

Particular attention has been paid to the role of 7-OH-DHEA in the brain as a neuroactive steroid. The pioneer works in this field were reviewed by Morfin and Stárka (2001). DHEA enhances memory and immune function but has no known dedicated receptor; local metabolism may govern its activity (Rose et al. 2001, Stárka et al. 2015). There were several contributions to knowledge on the localization, production in various areas of the brain, the conditions for 7-hydroxylation and further metabolism and the effects as a neurosteroid of 7-OH-DHEA (Jellinck et al. 2001, Jellinck et al. 2005, Li and Bigelow 2010, Rose et al. 2001, Kazihnitková et al. 2004). In contrast to DHEA, 7-hydroxylated derivatives were shown to mediate neuroprotection (Jellinck et al. 2005, Chalbot and Morfin 2005a,b, Pringle et al. 2003, Yau et al. 2003, Yau et al. 2006).

Several very important findings were that the interconvertible 7-oxygenated $\Delta^{5}$-steroids, namely $7 \alpha$-, 7 $\beta$-hydroxy-DHEA and 7-oxo-DHEA, can be substrates

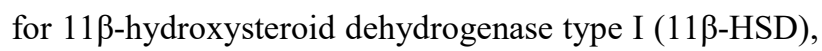
and so 7-OH-DHEA and other 7-hydroxylated $\mathrm{C}_{19}$-steroids function as factors maintaining the balance of local cortisol and cortisone concentrations (Hennebert et al. 2007a,b,c, Hennebert et al. 2009, Muller et al. 2006). These important interconversions locally controlling glucocorticoid levels in various tissues were also confirmed by other authors (Robinzon et al. 2003). The balance between $7 \beta$-hydroxy- $\Delta^{5}-\mathrm{C}_{19}$ steroids and their $7 \alpha$-hydroxy- counterparts is regulated by type 1 $11 \beta$-hydroxysteroid dehydrogenase (HSD11B1), which is capable (in addition to catalyzing the conversion of inactive cortisone to bioactive cortisol) of converting the $7 \alpha$-hydroxy- $\Delta^{5}-C_{19}$ steroids via 7 -oxo-steroid to their $7 \beta$-hydroxy- counterparts. This view was supported by the findings (Steckelbroeck et al. 2002) of high levels of CYP7B1 mRNA in brain tissue as well in combination with the ubiquitous presence of $7 \alpha$-hydroxylase activity in the human temporal lobe, which led to the assumption of a neuroprotective function of the enzyme such as regulation of the immune response or counteracting the deleterious effects of neurotoxic glucocorticoids, rather than a distinct brain specific function such as neurostimulation or neuromodulation. However, the role of these steroid transformations has been questioned, and it has been suggested that other as-yet unknown mechanisms responsible for the anti-glucocorticoid activity of DHEA and its metabolites may be found (Jellinck et al. 2001, Gottfried-Blackmore et al. 2013). Investigations of the metabolism of DHEA in $\mathrm{E}(\mathrm{t}) \mathrm{C}$ neuronal cells suggest that other alternate mechanisms than $11 \beta$-HSD must also be at play to explain the in vivo anti-glucocorticoid properties of DHEA and its 7-hydroxy-metabolites (Gottfried-Blackmore et al. 2013). 7-hydroxygenated metabolites of DHEA might be responsible for some of the functions previously ascribed to estrogens in the brain (Jellinck et al. 2001). 
Local control of the cortisol/cortisone ratio by 7-oxygenated DHEA metabolites was suggested as a possible factor in some neurodegenerative diseases such as Alzheimer's dementia (Kim et al. 2003, Bičíková et al. 2004, Vaňková et al. 2016) and psychiatric disorders such as depression and anxiety (Dušková et al. 2015, Hill et al. 2016), schizophrenia (Bičíková et al. 2011) and

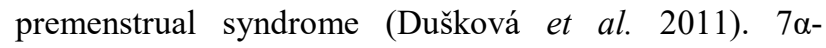
hydroxy-dehydroepiandrosterone is especially abundant in the brain, and in agreement with recent opinion plays a neuroprotective and immunoprotective role. 7-OHDHEA has also been found in cerebrospinal fluid (Kancheva et al. 2010, Kancheva et al. 2011, Sosvorová et al. 2015a,b). Decreased levels of DHEA were found in the cerebrospinal fluid of patients with Alzheimer's disease (AD), whereas its 7-oxygenated metabolites were not significantly changed (Kim et al. 2003). Increased 7-OH-DHEA was found in the plasma of AD patients (Kim et al. 2003, Attal-Khémis et al. 1998a), whereas others found lower levels in serum (Bičíková et al. 2004, Vaňková et al. 2016). Changes in the ratio of $7 \alpha / 7 \beta-$ hydroxy-DHEA were seen in patients with dementia, and this ratio was sufficient for the differentiation between vascular and Alzheimer's dementia (Kim et al. 2003). Levels of 7-OH-DHEA were found to be lower in the plasma of patients with Alzheimer's dementia (AD) than in controls, and even lower than in the plasma of patients with vascular dementia (Bičíková et al. 2004, Hampl and Bičíková 2010).

7-OH-DHEA has been measured in the individual brain regions of $\mathrm{AD}$ patients and aged nondemented controls. A significantly higher synthesis of $7 \alpha-$ hydroxy-DHEA in the frontal cortex was observed compared with that in other brain regions. In addition, a trend toward a significant negative correlation was found between the density of cortical amyloid deposits and the amount of $7 \alpha$-hydroxy-DHEA formed in the frontal cortex (Weill-Engerer et al. 2003). Additionally, a reduced $(50 \%)$ activity of 7 -hydroxylating CYP7B system was found in the hippocampus of primates with $\mathrm{AD}$ (Yau et al. 2003).

\section{Other effects of 7-OH-DHEA}

Since one close metabolite of 7-OH-DHA is 7-oxo-DHEA (Marwah et al. 2002), which is claimed to possess some thermogenic activity as an ergosteroid (Lardy et al. 1995), it is possible that at least some of the effects of 7-OH-DHEA are actually exerted by its metabolites.
Another related steroid, 5-androstene-3 $3,7 \beta, 17 \beta-$ triol, exhibits glucocorticoid-opposing and immunemodulating activity (Ahlem et al. 2011), and because its plasma levels positively correlate with BMI in healthy men and women, the authors suggested its compensatory role in preventing the development of metabolic syndrome (Auci et al. 2011). 5-androstene-3 $\beta, 7 \beta, 17 \beta$ triol ( $\beta$-AET), an active metabolite of dehydroepiandrosterone (DHEA), reversed the glucocorticoid induced suppression of IL-6, IL-8 and osteoprotegerin production (Malik et al. 2010). This steroid also influences estrogen receptor beta signaling (Pettersson et al. 2010).

Recently, attention has been given to various situations in which the levels of 7-OH-DHEA are different from control samples, as e.g. in the course of gravidity and following childbirth (Hill et al. 2010), during the female menstrual cycle in connection with changes of mood (Dušková et al. 2011), obesity (Sedláčková et al. 2012, Máčová et al. 2014), and during adrenal function testing by the ACTH or hypoglycemic tests (Dušková et al. 2016).

\section{Methods for the analysis and production of 7-OH-DHEA}

The first RIA of 7-OH-DHEA was described by Skinner et al. (1977). Lapčík later used this method to describe the course of plasma levels of men and women during their life spans, finding a remarkable decrease with age after 40 (Lapčík et al. 1998, Lapčík et al. 1999, Hampl et al. 2001). Presently, LC/MS or GC/MS methods are preferred (Hampl et al. 2002, Hill et al. 2001, Li et al. 2010, Sosvorová et al. 2015a, Matsuzaki et al. 2004).

Simplified chemical approaches leading to the production of $7 \alpha-/ 7 \beta$-hydroxy-DHEA in quantities that made them readily available to researchers, and the production of isotope-labeled compounds, ${ }^{2} \mathrm{H}-,{ }^{3} \mathrm{H}$-, and ${ }^{14} \mathrm{C}$-labeled $7 \alpha$ - $/ 7 \beta$-hydroxy-DHEA, were summarized by Feroud et al. (2012).

\section{Conflict of Interest}

There is no conflict of interest.

\section{Acknowledgements}

The study was supported by MH CZ - DRO (Institute of Endocrinology - EÚ, 00023761) and by the MEYS CR (OP RDE, Excellent research - ENDO.CZ). 


\section{References}

AHLEM CN, AUCI DL, NICOLETTI F, PIETERS R, KENNEDY MR, PAGE TM, READING CL, ENIOUTINA EY, FRINCKE JM: Pharmacology and immune modulating properties of 5-androstene-3 $\beta, 7 \beta, 17 \beta$-triol, a DHEA metabolite in the human metabolome. J Steroid Biochem Mol Biol 126: 87-94, 2011.

AKWA Y, MORFIN RF, ROBEL P, BAULIEU EE: Neurosteroid metabolism. 7 $\alpha$-Hydroxylation of dehydroepiandrosterone and pregnenolone by rat brain microsomes. Biochem J 288: 959-964, 1992.

AKWA Y, SANANÈS N, GOUÉZOU M, ROBEL P, BAULIEU EE, LE GOASCOGNE C: Astrocytes and neurosteroids: metabolism of pregnenolone and dehydroepiandrosterone. Regulation by cell density. $J$ Cell Biol 121: 135-143, 1993.

ATTAL-KHÉMIS S, DALMEYDA V, MICHOT JL, ROUDIER M, MORFIN R: Increased total 7 $\alpha$-hydroxydehydroepiandrosterone in serum of patients with Alzheimer's disease. J Gerontol A Biol Sci Med Sci 53: B125-B132, 1998a.

ATTAL-KHÉMIS S, DALMEYDA V, MORFIN R: Change of $7 \alpha$-hydroxy-dehydroepiandrosterone levels in serum of mice treated by cytochrome P450-modifying agents. Life Sci 63: 1543-1553, 1998b.

AUCI DL, AHLEM CN, KENNEDY MR, PAGE TM, READING CL, FRINCKE JM: A potential role for 5-androstene-3 $\beta, 7 \beta, 17 \beta$-triol in obesity and metabolic syndrome. Obesity (Silver Spring) 19: 806-811, 2011.

BAULIEU EE: Dehydroepiandrosterone (DHEA): a fountain of youth? J Clin Endocrinol Metab 81: 3147-3151, 1996.

BEAN R, SECKL JR, LATHE R, MARTIN C: Ontogeny of the neurosteroid enzyme Cyp7b in the mouse. Mol Cell Endocrinol 174: 137-144, 2001.

BIČÍKOVÁ M, ŘíPOVÁ D, HILL M, JIRÁK R, HAVLÍKOVÁ H, TALLOVÁ J, HAMPL R: Plasma levels of 7-hydroxylated dehydroepiandrosterone (DHEA) metabolites and selected amino-thiols as discriminatory tools of Alzheimer's disease and vascular dementia. Clin Chem Lab Med 42: 518-524, 2004.

BIČÍKOVÁ M, HAMPL R, HILL M, ŘÍPOVA D, MOHR P, PUTZ Z: Neuro- and immunomodulatory steroids and other biochemical markers in drug-naive schizophrenia patients and the effect of treatment with atypical antipsychotics. Neuro Endocrinol Lett 32: 141-147, 2011.

CEDARD L, FILLMANN B, KNUPPEN R, LISBOA BP, BREUER H: The metabolism and aromatization of 7-substituted C-19 steroids in the placenta. Hoppe Seylers Z Physiol Chem 338: 89-99, 1964.

CHALBOT S, MORFIN R: Neurosteroids: metabolism in human intestine microsomes. Steroids 70: 319-326, $2005 \mathrm{a}$.

CHALBOT S, MORFIN R: Human liver S9 fractions: metabolism of dehydroepiandrosterone, epiandrosterone, and related 7-hydroxylated derivatives. Drug Metab Dispos 33: 563-569, 2005b.

CHALBOT S, MORFIN R: Dehydroepiandrosterone metabolites and their interactions in humans. Drug Metabol Drug Interact 22: 1-23, 2006.

CHALBOT S, MORFIN R: Cytochrome P450-7B1 and 11ß-hydroxysteroid dehydrogenase type 1 distribution in human tissues. Horm Mol Biol Clin Investig 9: 179-189, 2012.

CHMIELEWSKI V, DRUPT F, MORFIN R: Dexamethasone-induced apoptosis of mouse thymocytes: prevention by native 7alpha-hydroxysteroids. Immunol Cell Biol 78: 238-246, 2000.

COUCH RA, SKINNER SJ, TOBLER CJ, DOOUSS TW: The in vitro synthesis of 7-hydroxy-dehydroepiandrosterone by human mammary tissues. Steroids 26: 1-15, 1975.

DOOSTZADEH J, MORFIN R: Studies of the enzyme complex responsible for pregnenolone and dehydroepiandrosterone $7 \alpha$-hydroxylation in mouse tissues. Steroids 61: 613-620, 1996.

DOOSTZADEH J, COTILLON AC, MORFIN R: Dehydroepiandrosterone $7 \alpha$ - and $7 \beta$-hydroxylation in mouse brain microsomes. Effects of cytochrome P450 inhibitors and structure-specific inhibition by steroid hormones. J Neuroendocrinol 9: 923-928, 1997.

DOOSTZADEH J, COTILLON AC, BENALYCHÉRIF A, MORFIN R: Inhibition studies of dehydroepiandrosterone 7 $\alpha$ - and 7 $\beta$ - hydroxylation in mouse liver microsomes. Steroids 63: 608-614, 1998.

DULOS J, KAPTEIN A, KAVELAARS A, HEIJNEN C, BOOTS A: Tumour necrosis factor- $\alpha$ stimulates dehydroepiandrosterone metabolism in human fibroblast-like synoviocytes: a role for nuclear factor-kappaB and activator protein- 1 in the regulation of expression of cytochrome p450 enzyme 7b. Arthritis Res Ther 7: R1271-R1280, 2005. 
DUŠKOVÁ M, ŠIMU゚NKOVÁ K, HILL M, STÁRKA L: 7-hydroxylated derivatives of dehydroepiandrosterone as possibly related to menstrual mood change in healthy women. Endocr Regul 45: 131-137, 2011.

DUŠKOVÁ M, HILL M, BIČÍKOVÁ M, ŠRÁMKOVÁ M, ŘÍPOVÁ D, MOHR P, STÁRKA L: Steroid metabolom in men with mood and anxiety disorders. Physiol Res 64 (Suppl 2): S275-S282, 2015.

DUŠKOVÁ M, SOSVOROVÁ L, HILL M, ŠIMŮNKOVÁ K, KOSÁK M, KRŠEK M, HÁNA V, STÁRKA L: The response of C19- $\triangle 5$-steroids to ACTH stimulation and hypoglycemia in insulin tolerance test for adrenal insufficiency. Prague Med Report 117: 98-107, 2016.

FAREDIN I, FAZEKAS AG, TÓTH I, KÓKAI K, JULESZ M: Transformation in vitro of [4-14-C]dehydroepiandrosterone into 7-oxygenated derivatives by normal human male and female skin tissue. $J$ Invest Dermatol 52: 357-361, 1969.

FERROUD C, REVIAL G, MORFIN R: Chemical and biochemical approaches to the production of 7-hydroxylated C19-steroids. Horm Mol Biol Clin Investig 10: 293-299, 2012.

GOTTFRIED-BLACKMORE A, JELLINCK PH, VECCHIARELLI HA, MASHEEB Z, KAUFMANN M, MCEWEN BS, BULLOCH K: $7 \alpha$-hydroxylation of dehydroepiandrosterone does not interfere with the activation of glucocorticoids by $11 \beta$-hydroxysteroid dehydrogenase in $\mathrm{E}(\mathrm{t}) \mathrm{C}$ cerebellar neurons. $J$ Steroid Biochem Mol Biol 138: 290-297, 2013.

HAMPL R, BIČÍKOVÁ M: Neuroimmunomodulatory steroids in Alzheimer dementia. J Steroid Biochem Mol Biol 119: 97-104, 2010.

HAMPL R, STÁRKA L: In vitro metabolic transformation of $7 \alpha$-hydroxy-dehydroepiandrosterone in rat liver, adrenal and testis. Endocr Exper 1: 5-13, 1967.

HAMPL R, STÁRKA L: Epimerisation of naturally occurring C19-steroid allylic alcohols by rat liver preparations. J Steroid Biochem 1: 47-56, 1969.

HAMPL R, MORFIN R, STÁRKA L: 7-Hydroxylated C19-steroids: what are they good for? Endocr Regul 31: 211-218, 1997.

HAMPL R, LAPČÍK O, HILL M, KLAK J, KASAL A, NOVÁČEK A, ŠTERZL I, ŠTERZL J, STÁRKA L: 7-Hydroxy-dehydroepiandrosterone - a natural antiglucocorticoid and a candidate for steroid replacement therapy? Physiol Res 49 (Suppl 1): S107-S112, 2000a.

HAMPL R, HILL M, ŠTERZL I, STÁRKA L: Immunomodulatory 7-hydroxylated metabolites of dehydroepiandrosterone are present in human semen. J Steroid Biochem Mol Biol 75: 273-276, $2000 \mathrm{~b}$.

HAMPL R, HILL M, STÁRKA L: 7-Hydroxydehydroepiandrosterone epimers in the life span. J Steroid Biochem Mol Biol 78: 367-372, 2001.

HAMPL R, HILL M, STÁRKA L: Detection and quantification of 7-hydroxydehydroepi- androsterone epimers in three body fluids. Coll Czech Chem Commun 67: 10-18, 2002.

HEINRICHS WL, COLÁS A: The selective stimulation, inhibition, and physicochemical alteration of the 7- and 16- $\alpha$ hydroxylases of 3- $\beta$-hydroxyandrost-5-en-17-one and drug-metabolizing enzymes in hepatic microsomal fractions. Biochemistry 7: 2273-2280, 1968.

HEINRICHS WL, MUSHEN RL, COLÁS A: The 7- $\beta$-hydroxylation of 3- $\beta$-hydroxyandrost-5-en-17-one by hepatic microsomes. Steroids 9: 23-40, 1967.

HENNEBERT O, CHALBOT S, ALRAN S, MORFIN R: Dehydroepiandrosterone 7 $\alpha$-hydroxylation in human tissues: possible interference with type $111 \beta$-hydroxysteroid dehydrogenase-mediated processes. J Steroid Biochem Mol Biol 104: 326-333, 2007a.

HENNEBERT O, LE MÉE S, PERNELLE C, MORFIN R: $5 \alpha$-androstane-3 $\beta, 7 \alpha, 17 \beta$-triol and $5 \alpha$-androstane$3 \beta, 7 \beta, 17 \beta$-triol as substrates for the human $11 \beta$-hydroxysteroid dehydrogenase type 1. Steroids 72: 855-864, 2007b.

HENNEBERT O, PERNELLE C, FERROUD C, MORFIN R: $7 \alpha$ - and $7 \beta$-hydroxy-epiandrosterone as substrates and inhibitors for the human 11ß-hydroxysteroid dehydrogenase type 1. J Steroid Biochem Mol Biol 105: 159-165, $2007 \mathrm{c}$.

HENNEBERT O, MONTES M, FAVRE-REGUILLON A, CHERMETTE H, FERROUD C, MORFIN R: Epimerase activity of the human $11 \beta$-hydroxysteroid dehydrogenase type 1 on 7-hydroxylated C19-steroids. $J$ Steroid Biochem Mol Biol 114: 57-63, 2009. 
HILL M, LAPČÍK O, HAVLÍKOVÁ, MORFIN R, HAMPL R: 7-Hydroxydehydroepiandrosterone epimers in human serum and saliva. Comparison of gas chromatography-mass spectrometry and radioimmunoassay. J Chromatogr A 935: 297-307, 2001.

HILL M, PAŘÍZEK A, KANCHEVA R, DUŠKOVÁ M, VELÍKOVÁ M, KŘÍŽ L, KLÍMKOVÁ M, PAŠKOVÁ A, ŽIŽKA Z, MATUCHA P, MELOUN M, STÁRKA L: Steroid metabolome in plasma from the umbilical artery, umbilical vein, maternal cubital vein and in amniotic fluid in normal and preterm labor. J Steroid Biochem Mol Biol 121: 594-610, 2010.

HILL M, ŘÍPOVÁ D, MOHR P, KRATOCHVÍLOVÁ Z, VELIKOVÁ M, BIČÍKOVÁ M, DUŠKOVÁ M, STÁRKA L: Circulating C19 steroids and progesterone metabolites in women with acute depression and anxiety disorders. Horm Mol Biol Clin Investig 26: 153-164, 2016.

JANATA J, JANATOVÁ V, STÁRKA L: Aromatisation of 7 $\alpha$-hydroxydehydroepiandrosterone and other androgens by ovarian and placental tissue culture. Akad Wiss(Berlin) Abh, Klasse Medizin 3: 783-786, 1965.

JELLINCK PH, LEE SJ, MCEWEN BS: Metabolism of dehydroepiandrosterone by rat hippocampal cells in culture: possible role of aromatization and 7-hydroxylation in neuroprotection. J Steroid Biochem Mol Biol 78: 313-317, 2001

JELLINCK PH, CROFT G, MCEWEN BS, GOTTFRIED-BLACKMORE A, JONES G, BYFORD V, BULLOCH K: Metabolism of dehydroepiandrosterone by rodent brain cell lines: relationship between 7-hydroxylation and aromatization. J Steroid Biochem Mol Biol 93: 81-86, 2005.

KANCHEVA R, HILL M, NOVÁK Z, CHRASTINA J, VELÍKOVÁ M, KANCHEVA L, RÍHA I, STÁRKA L: Peripheral neuroactive steroids may be as good as the steroids in the cerebrospinal fluid for the diagnostics of CNS disturbances. J Steroid Biochem Mol Biol 119: 35-44, 2010.

KANCHEVA R, HILL M, NOVÁK Z, CHRASTINA J, KANCHEVA L, STÁRKA L: Neuroactive steroids in periphery and cerebrospinal fluid. Neuroscience 191: 22-27, 2011.

KAZIHNITKOVÁ H, TEJKALOVÁ H, BENESOVÁ O, BICÍKOVÁ M, HILL M, HAMPL R: Simultaneous determination of dehydroepiandrosterone, its 7-hydroxylated metabolites, and their sulfates in rat brain tissues. Steroids 69: 667-674, 2004.

KHALIL MW, STRUTT B, VACHON D, KILLINGER DW: Metabolism of dehydroepiandrosterone by cultured human adipose stromal cells: identification of 7 -hydroxy-dehydroepiandrosterone as a major metabolite using high performance liquid chromatography and mass spectrometry. J Steroid Biochem Mol Biol 46: 585-595, 1993.

KHALIL MW, STRUTT B, KILLINGER DW: $7 \alpha$-Hydroxylation of the adrenal androgens dehydroepiandrosterone and androst-5-ene-3 $\beta, 17 \beta$-diol predominates in differentiating human adipose stromal cells. Ann N Y Acad Sci 774: 316-318, 1995.

KIM SB, HILL M, KWAK YT, HAMPL R, JO DH, MORFIN R: Neurosteroids: Cerebrospinal fluid levels for Alzheimer's disease and vascular dementia diagnostics. J Clin Endocrinol Metab 88: 5199-5206, 2003.

KIM SB, CHALBOT S, POMPON D, JO DH, MORFIN R: The human cytochrome P4507B1: catalytic activity studies. J Steroid Biochem Mol Biol 92: 383-389, 2004.

LAFAYE P, CHMIELEWSKI V, NATO F, MAZIÉ JC, MORFIN R: The 7 $\alpha$-hydroxysteroids produced in human tonsils enhance the immune response to tetanus toxoid and Bordetella pertussis antigens. Biochim Biophys Acta 1472: 222-231, 1999.

LAPČÍK O, HAMPL R, HILL M, BIČÍKOVÁ M, STÁRKA L: Immunoassay of 7-hydroxysteroids: 1. Radioimmunoassay of 7beta-hydroxydehydroepiandrosterone. J Steroid Biochem Mol Biol 67: 439-445, 1998.

LAPČÍK O, HAMPL R, HILL M, STÁRKA L: Immunoassay of 7-hydroxysteroids: 2. Radio- imunoassay of 7alphahydroxy-dehydroepiandrosterone. J Steroid Biochem Mol Biol 71: 231-237, 1999.

LARDY H, PARTRIDGE B, KNEER N, WEI Y: Ergosteroids: induction of thermogenic enzymes in liver of rats treated with steroids derived from dehydroepiandrosterone. Proc Natl Acad Sci USA 92: 6617-6619, 1995.

LATHE R: Steroid and sterol 7-hydroxylation: ancient pathways. Steroids 67: 967-977, 2002.

LI A, BIGELOW JC: The 7-hydroxylation of dehydroepiandrosterone in rat brain. Steroids 75: 404-410, 2010. 
LI A, MAY MP, BIGELOW JC: An LC/MS method for the quantitative determination of $7 \alpha-\mathrm{OH}$ DHEA and $7 \beta-\mathrm{OH}$ DHEA: an application for the study of the metabolism of DHEA in rat brain. Biomed Chromatogr 24: 833-837, 2010 .

LI H, LIU HM, GE W, HUANG L, SHAN L: Synthesis of $7 \alpha$-hydroxy-dehydroepiandrosterone and $7 \beta$-hydroxydehydroepiandrosterone. Steroids 70: 970-973, 2005.

MÁČOVÁ L, BIČÍKOVÁ M, ZAMRAZILOVÁ H, HILL M, KAZIHNITKOVÁ H, SEDLÁČKOVÁ B, STÁRKA L: Reduced levels of circulating 7alpha-hydroxy-dehydroepiandrosterone in treated adolescent obese patients. Physiol Res 63: 95-101, 2014.

MALIK AK, KHALDOYANIDI S, AUCI DL, MILLER SC, AHLEM CN, READING CL, PAGE T, FRINCKE JM: 5 -Androstene-3 $\beta, 7 \beta, 17 \beta$-triol ( $\beta$-AET) slows thermal injury induced osteopenia in mice: relation to aging and osteoporosis. PLoS One 5: e13566, 2010.

MARTIN C, BEAN R, ROSE K, HABIB F, SECKL J: cyp7b1 catalyses the 7alpha-hydroxylation of dehydroepiandrosterone and 25-hydroxycholesterol in rat prostate. Biochem J 355: 509-515, 2001.

MARWAH A, MARWAH P, LARDY H: Ergosteroids VI. Metabolism of dehydroepiandrosterone by rat liver in vitro: a liquid chromtograpúhic-mass spectrometric study. J Chromatog B 767: 285-299, 2002.

MATSUZAKI Y, YOSHIDA S, HONDA A, MIYAZAKI T, TANAKA N, TAKAGIWA A, FUJIMOTO Y, MIYAZAKI H: Simultaneous determination of dehydroepiandrosterone and its 7-oxygenated metabolites in human serum by high-resolution gas chromatography-mass spectrometry. Steroids 69: 817-824, 2004.

MORFIN R, COURCHAY G: Pregnenolone and dehydroepiandrosterone as precursors of native 7-hydroxylated metabolites which increase the immune response in mice. J Steroid Biochem Mol Biol 50: 91-100, 1994.

MORFIN R, STÁRKA L: Neurosteroid 7-hydroxylation products in the brain. Int Rev Neurobiol 46: 79-95, 2001.

MORFIN R, LAFAYE P, COTILLON AC, NATO F, CHMIELEWSKI V, POMPON D: 7alpha-hydroxydehydroepiandrosterone and immune response. Ann N Y Acad Sci 917: 971-982, 2000.

MULLER C, CLUZEAUD F, PINON GM, RAFESTIN-OBLIN ME, MORFIN R: Dehydroepiandrosterone and its 7-hydroxylated metabolites do not interfere with the transactivation and cellular trafficking of the glucocorticoid receptor. J Steroid Biochem Mol Biol 92: 469-476, 2004.

MULLER C, HENNEBERT O, MORFIN R: The native anti-glucocorticoid paradigm. J Steroid Biochem Mol Biol 100: 95-105, 2006.

OKADA M, FUKUSHIMA DK, GALLAGHER TF: Isolation and characterization of 3beta-hydroxy- $\Delta^{5}$-steroids in adrenal carcinoma. $J$ Biol Chem 234: 1688-1692, 1959.

PELISSIER MA, TRAP C, MALEWIAK MI, MORFIN R: Antioxidant effects of dehydroepiandrosterone and $7 \alpha-$ hydroxy-dehydroepiandrosterone in the rat colon, intestine and liver. Steroids 69: 137-144, 2004.

PETTERSSON H, LUNDQVIST J, NORLIN M: Effects of CYP7B1-mediated catalysis on estrogen receptor activation. Biochim Biophys Acta 1801: 1090-1097, 2010.

POHANKA M, HAMPL R, ŠTERZL I, STÁRKA L: Steroid hormones in human semen with particular respect to dehydroepiandrosterone and its immunomodulatory metabolites. Endocr Regul 36: 79-86, 2002.

PRINGLE AK, SCHMIDT W, DEANS JK, WULFERT E, REYMANN KG, SUNDSTROM LE: 7-Hydroxylated epiandrosterone (7-OH-EPIA) reduces ischaemia-induced neuronal damage both in vivo and in vitro. Eur $J$ Neurosci 18: 117-124, 2003.

ROBINZON B, MICHAEL KK, RIPP SL, WINTERS SJ, PROUGH RA: Glucocorticoids inhibit interconversion of 7-hydroxy and 7-oxo metabolites of dehydroepiandrosterone: a role for 11ß-hydroxysteroid dehydrogenases? Arch Biochem Biophys 412: 251-258, 2003.

ROBINZON B, MILLER KK, PROUGH RA: Biosynthesis of [3H]7 $\alpha$-hydroxy-, $7 \beta$-hydroxy-, and 7-oxodehydroepiandrosterone using pig liver microsomal fractions. Anal Biochem 333: 128-135, 2004.

ROSE K, ALlAN A, GAUldie S, STAPLETON G, DOBBIE L, DOTT K, MARTIN C, WANG L, HEDLUND E, SECKL JR, GUSTAFSSON JA, LATHE R: Neurosteroid hydroxylase CYP7B: vivid reporter activity in dentate gyrus of gene-targeted mice and abolition of a widespread pathway of steroid and oxysterol hydroxylation. J Biol Chem 276: 23937-23944, 2001. 
ROSE KA, STAPLETON G, DOTT K, KIENY MP, BEST R, SCHWARZ M, RUSSELL DW, BJÖRKHEM I, SECKL J, LATHE R: Cyp7b, a novel brain cytochrome P450, catalyzes the synthesis of neurosteroids $7 \alpha$-hydroxy dehydroepiandrosterone and 7 $\alpha$-hydroxy pregnenolone. Proc Natl Acad Sci U S A 94: 4925-4930, 1997.

SEDLÁČKOVÁ B, DUŠÁTKOVÁ L, ZAMRAZILOVÁ H, MATUCHA P, BIČÍKOVÁ M, STÁRKA L: 7-oxygenated derivatives of dehydroepiandrosterone and obesity. Prague Med Report 113: 147-155, 2012.

SKINNER SJ, TOBLER CJ, COUCH RA: A radioimmunoassay for $7 \alpha$-hydroxy-dehydroepiandrosterone in human plasma. Steroids 30: 315-330, 1977.

SKINNER SJ, COUCH RA, THAMBYAH S, DOBBS RJ, JORDAN SM, MASON B, KAY RG: he relationship of plasma $7 \alpha$-hydroxy dehydroepiandrosterone to disease stage and adrenal androgens in breast cancer patients. Eur J Cancer 16: 223-228, 1980.

SOSVOROVÁ L, BIČÍKOVÁ M, MOHAPL M, HAMPL R: Steroids and their metabolites in CSF from shunt as potential predictors of further disease progression in patients with hydrocephalus and the importance of 11ß-hydroxysteroid dehydrogenase. Horm Mol Biol Clin Investig 10: 287-292, 2012.

SOSVOROVÁ L, VITKŮ J, CHLUPÁČOVÁ T, MOHAPL M, HAMPL R: Determination of seven selected neuro- and immunomodulatory steroids in human cerebrospinal fluid and plasma using LC-MS/MS. Steroids 98: 1-8, $2015 \mathrm{a}$.

SOSVOROVA L, HILL M, MOHAPL M, VITKU J, HAMPL R: Steroid hormones in prediction of normal pressure hydrocephalus. J Steroid Biochem Mol Biol 152: 124-132, 2015 b.

STAPLETON G, STEEL M, RICHARDSON M, MASON JO, ROSE KA, MORRIS RG, LATHE R: A novel cytochrome P450 expressed primarily in brain. J Biol Chem 270: 29739-29745, 1995.

STÁRKA L: $7 \alpha$-Hydroxylierung von Dehydroepiandrosteron in menschlichen Nebenierenrinde und Leber. Naturwiss 52: 499, 1965.

STÁRKA L: Reaktion der Steroide mit tert.-Butylperbenzoat I. Über die 7-Acyloxylierung $\Delta 5$-ungesattigter Steroide. Coll Czechoslov Chem Commun 26: 2452-2456, 1961.

STÁRKA L, HAMPL R: Die Isolation des $7 \alpha$-Hydroxdehydroepiandrosterone Sulphates aus dem menschlichen Plasma. Naturwiss 51: 164-165, 1964.

STÁRKA L, KU゚TOVÁ J: 7-Hydroxylation of dehydroepiandrosterone by rat liver homogenate. Biochim Biophys Acta 36: 76-82, 1962.

STÁRKA L, SYHORA K: The method of acyloxylation of steroid substances in the neighbourhood of double bond (in Czech). CZ patent No. 100325/1960.

STÁRKA L, ŠULCOVÁ J, ŠILINK K: Die Harnausscheidung des 7-Hydroxydehydroepi androsteronsulfats. Clin Chim Acta 7: 309-316, 1962.

STÁRKA L, JANATA J, NOVÁK J: Aromatisation of 7 $\alpha$-hydroxydehydroepiandrosteron and its 3-sulphate by ovarian and placental tissue culture. $J$ Endocrin 34: 57-60, 1966.

STÁRKA L, DÖLLEFELD E, BREUER H: Biogenese von freiem und sulfatiertem $7 \alpha$-Hydroxy- androstenolon in Zellfraktionen der Rattenleber. Z Physiol Chem 348: 293-302, 1967.

STÁRKA L, HILL M, HAMPL R, MORFIN R, MALEWIAK MI, KOLENA J, SCSUKOVÁ S: On the mechanism of antiglucocorticoid action of $7 \alpha$-hydroxy-dehydroepiandrosterone: Effect on DNA binding of dexamethasonelabelled glucocorticoid receptor and on membrane fluidity. Coll Czechoslov Chem Commun 63: 1683-1698, 1998.

STÁRKA L, HILL M, KANCHEVA R, NOVÁK Z, CHRASTINA J, POHANKA M, MORFIN R: 7-Hydroxylated derivatives of dehydroepiandrosterone in the human ventricular cerebrospinal fluid. Neuro Endocrinol Lett 30: 368-372, 2009.

STÁRKA L, DUŠKOVÁ M, HILL M: Dehydroepiandrosterone as a neurosteroid. $J$ Steroid Biochem Mol Biol 145: 254-260, 2015.

STECKELBROECK S, WATZKA M, LÜTJOHANN D, MAKIOLA P, NASSEN A, HANS VH, CLUSMANN H, REISSINGER A, LUDWIG M, SIEKMANN L, KLINGMÜLLER D: Characterization of the dehydroepiandrosterone (DHEA) metabolism via oxysterol 7alpha-hydroxylase and 17-ketosteroid reductase activity in the human brain. $J$ Neurochem 83: 713-726, 2002. 
ŠTERZL I, HAMPL R, ŠTERZL J, VOTRUBA J, STÁRKA L: 7ß-OH-DHEA counteracts dexamethasone induced suppression of primary immune response in murine spleenocytes. J Steroid Biochem Mol Biol 71: 133-137, 1999.

ŠTERZL I, HAMPL R, HILL M, HRDÁ P, MATUCHA P: Immunomodulatory cytokines in human seminal plasma correlate with immunomodulatory steroids. Steroids 68: 725-731, 2003.

ŠULCOVÁ J, STÁRKA L: Extrahepatic 7alpha-hydroxylation of dehydroepiandrosterone. Experientia 19: 1-4, 1963.

ŠULCOVÁ J, STÁRKA L: Characterisation of microsomal dehydroepiandrosterone 7-hydroxylase from rat liver. Steroids 12: 113-126, 1968.

ŠULCOVÁ J, STÁRKA L, JIRÁSEK JE: $7 \alpha$-Hydroxylation of dehydroepiandrosterone by the steroidogenic tissues and the liver of human embryo in the first trimester of pregnancy in vitro. Gen Comp Endocr 9: 497, 1967.

ŠULCOVÁ J, ČAPKOVÁ A, JIRÁSEK JE, STÁRKA L: 7-hydroxylation of dehydroepiandrosterone in human foetal liver, adrenals and chorion in vitro. Acta Endocrinol (Copenh) 59: 1-9, 1968.

ŠULCOVÁ J, JIRÁSEK JE, CARLSTEDT-DUKE J, STÁRKA L: 7-Hydroxylation of dehydroepiandrosterone in human amniotic epithelium. J Steroid Biochem 7: 101-104, 1976.

ŠULCOVÁ J, STÁRKA L, JIRÁSEK JE: Metabolism of C19-delta-5-3ß-hydroxysteroids in the term human amnion. Endocrinol Exp 16: 9-17, 1982.

TABEI T, FUKUSHIMA K, HEINRICHS WL: Enzymatic oxidation and reduction of C19-delta5-3betahydroxysteroids by hepatic microsomes. IV. Induction of DHEA hydroxylases and aminopyrine N-demethylase in immature male rats by androgens. Endocrinology 96: 815-819, 1975.

TRAP C, NATO F, CHALBOT S, KIM SB, LAFAYE P, MORFIN R: Immunohistochemical detection of the human cytochrome P4507B1: production of a monoclonal antibody after cDNA immunization. J Neuroimmunol 159: 41-47, 2005.

VAŇKOVÁ M, HILL M, RUSINA R, VAŇKOVÁ H, VČELÁK J, VACÍNOVÁ G, DVOŘÁKOVÁ K, LUKÁŠOVÁ P, VEJRAŽKOVÁ D, VELÍKOVÁ M, JAROLÍMOVÁ E, HOLMEROVÁ I, BENDLOVÁ B, STÁRKA L: Circulating steroids as predictors of Alzheimer's disease. J Steroid Biochem Mol Biol 158: 157-177, 2016.

VICO P, CAUET G, ROSE K, LATHE R, DEGRYSE E: Dehydroepiandrosterone (DHEA) metabolism in Saccharomyces cerevisiae expressing mammalian steroid hydroxylase CYP7B: Ayr1p and Fox $2 p$ display 17ß-hydroxysteroid dehydrogenase activity. Yeast 19: 873-886, 2002.

WEILL-ENGERER S, DAVID JP, SAZDOVITCH V, LIERE P, SCHUMACHER M, DELACOURTE A, BAULIEU EE, AKWA Y: In vitro metabolism of dehydroepiandrosterone (DHEA) to $7 \alpha$-hydroxy-DHEA and Delta5androstene-3 $\beta, 17 \beta$-diol in specific regions of the aging brain from Alzheimer's and non-demented patients. Brain Res 969: 117-125, 2003.

YAU JL, RASMUSON S, ANDREW R, GRAHAM M, NOBLE J, OLSSON T, FUCHS E, LATHE R, SECKL JR: Dehydroepiandrosterone 7-hydroxylase CYP7B: predominant expression in primate hippocampus and reduced expression in Alzheimer's disease. Neuroscience 121: 307-314, 2003.

YAU JL, NOBLE J, GRAHAM M, SECKL JR: Central administration of a cytochrome P450-7B product 7 $\alpha$-hydroxypregnenolone improves spatial memory retention in cognitively impaired aged rats. $J$ Neurosci $\mathbf{2 6}$ : 11034-11040, 2006.

YOSHIDA S, HONDA A, MATSUZAKI Y, FUKUSHIMA S, TANAKA N, TAKAGIWA A, FUJIMOTO Y, MIYAZAKI H, SALEN G: Anti-proliferative action of endogenous dehydroepiandrosterone metabolites on human cancer cell lines. Steroids 68: 73-83, 2003. 